Al-Muaddib : Jurnal IImu-IImu Sosial \& Keislaman http://jurnal.um-tapsel.ac.id/index.php/al-muaddib/

issn online : 2549-0427 | issn cetak : 2528-2492 Volume 1 Nomor 2 (Januari-Juni) 2019

\title{
TRILOGI SISTEM PENDIDIKAN PESANTREN MUHAMMADIYAH: SUATU PENGANTAR
}

\author{
Dosen Institut Agama Islam Negeri Padangsidimpuan \\ Ichwansyah Tampubolon \\ Email: Ichwansyahtampubolon@gmail.com
}

\begin{abstract}
PontrenMu has three patterns of Islamic education system, namely: the madrasa system, the Islamic Boarding School system, and expertise (takhaşssuş) system. The madrasa system is a model of modernization of Islamic traditional educational system and Islamic Boarding School system seems as a model of "postmodernized" high school (sekolah) educational system. Meanwhile, expertise (takhaşşsus) system can be called as a neo-postmodernized Islamic Boarding School system in which the graduate Islamic educational system integrating with traditional Islamic education in a spesific pattern (pesantren luhur/ma' had `aly). All of that Islamic educational systems are oriented to realize the vision and mission of Muhammadiyah in order to produce the cadres of ulema-intellectual or intellectual-ulema formally and simultaneously. Besides of being the alternative strategies for improvement of Islamic educational system of Muhammadiyah in both levels of high and graduate school, the three patterns of Islamic education system are also being solutions for fulfillment of demands and needs of Moslem communities in contemporary era.
\end{abstract}

Key words: PontrenMu education system, madrasa, Islamic Boarding System, expertise (takhaşşsuş)

\section{PENDAHULUAN}

Hingga dewasa ini, Muhammadiyah telah mendirikan sekitar 180 pesantren. ${ }^{1}$ Kehadiran sejumlah Pesantren Muhammadiyah (selanjutnya disebut PontrenMu) sebagai salah satu model pendidikan Islam di Indonesia itu tidak terlepas dari upaya untuk memberikan solusi-alternatif atas kekurangmampuan pesantren tradisional menciptakan dan meningkatkan kemampuan para santri secara integral-holistik. PontrenMu berupa memadukan kemampuan aspek kognitif, afektif, dan psikomotorik para santrinya agar mereka tidak tertinggal di bidang agama maupun ilmu pengetahuan saintifik dan keterampilan hidup. PontrenMu, secara internal, bertujuan untuk memenuhi tuntutan kebutuhan umat dan sekaligus untuk menjamin ketersediaan dan keberlanjutan Sumber Daya Manusia yang berkualitas di bidang keislaman, keilmuan, dan kejuangan di bidang dakwah, ketarjihan, kaderisasi, dan regenerasi kepemimpinan di lingkungan Muhammadiyah, khususnya. ${ }^{2}$ Jika pesantren tradisional pada umumnya bertujuan untuk

${ }^{1}$ Di samping itu, Muhammadiyah juga relatif berhasil memodernisasi pendidikan Islam dalam bentuk pendidikan Islam modern sejak tingkat Taman Kanak-Kanak (PAUD/TK) hingga tingkat Perguruan Tinggi (PT), seperti: 14.346 (PAUD/TK), 2.604 SD/MI, 1.772 SMP/MTs., 1.143 SMA/SMK/MA, 71 Sekolah Luar Biasa (SLB), 102 (Pondok Pesantren), dan lain-lain. Pimpinan Pusat Muhammadiyah, Laporan Pimpinan Pusat Muhammadiyah Periode 2010-2015, (Jakarta: PP Muhammadiyah, 2015), hlm. 23. Bandingkan, Lembaga Pengembangan Pondok Pesantren Pimpinan Pusat Muhammadiyah, Kurikulum Pondok Pesantren Muhammadiyah Tahun 2016, (Jakarta: PP Muhammadiyah, 2016), hlm. 8. Lazuardi, Sistem dan Orientasi Pendidikan Pesantren Muhammadiyah di Sumatera Utara (Disertasi), (Medan: Pascasarjana UIN Sumatera Utara, 2018), hlm.14

${ }^{2}$ Lembaga Pengembangan Pesantren (LP2) Pimpinan Pusat Muhammadiyah, Standar Pendidikan Pesantren Muhammadiyah Tahun 2017, (Jakarta: PP Muhammadiyah, 2017), hlm. 1011 
Al-Muaddib : Jurnal IImu-IImu Sosial \& Keislaman http://jurnal.um-tapsel.ac.id/index.php/al-muaddib/ issn online : 2549-0427 | issn cetak : 2528-2492 Volume 1 Nomor 2 ( Januari-Juni) 2019

melahirkan ulama yang menguasai Ilmu-Ilmu Keislaman Klasik (gaya lama), maka PontrenMu bertujuan untuk menciptakan kader ulama-intelektual yang memiliki kapasitas dan kemampuan dalam bidang Ilmu-Ilmu Keislaman, Ilmu-Ilmu Umum, keterampilan hidup (skills), dan bidang kepemimpinan guna kepentingan regenerasi pengelolaan Amal Usaha Muhammadiyah (AUM) dan pelanjut perjuangan organisasi Muhammadiyah. ${ }^{3}$ Selanjutnya, secara eksternal, PesantreMu juga berupaya melahirkan alumni yang mampu memberikan solusi atas berbagai persoalan umat, negara, dan bangsa Indonesia serta kepentingan kemanusiaan sedunia sejalan dengan dinamika perkembangan zaman kekinian.

Dalam memenuhi tugas dan tanggung-jawab yang sangat besar itu, PontrenMu tidak jarang menghadapi hambatan dan tantangan. Ironisnya, dalam hal ini PontrenMu ternyata tidak memiliki acuan dan model penyelenggaraan pendidikan pesantren yang baku, utuh, dan komprehensif secara nasional. Terkesan PontrenMu terpinggirkan atau kurang memperoleh perhatian secara serius dari persyarikatan Muhammadiyah, apabila dibandingkan dengan pembinaan dan perkembangan sekolah-sekolah dan perguruan tinggi-perguruan tinggi Muhammadiyah. Sistem pembinaan PontrenMu, selama beberapa dasawarsa terkesan hanya "dicangkokkan atau disisipkan" dalam sistem pembinaan dan tata kelola lembaga pendidikan dasar dan menengah Muhammadiyah di bawah wewenang Majlis Pendidikan Dasar dan Menengah (Dikdasmen) Muhammadiyah. Buktinya, hanya sedikit sekali ketentuan dan petunjuk tentang penyelengaraan PontrenMu di dalam Ketentuan Majlis Pendidikan Dasar dan Menengah Pimpinan Pusat Muhammadiyah Nomor: 10/KTN/I.4/F/2013. Dampaknya, PontrenMu banyak yang hidupnya berjalan di tempat (lâ yamûtu wa lâ yahyâ), perkembangannya relatif sangat lambat, dan bahkan terpaksa ditutup. Sementara itu, PesantrenMu yang dipandang relatif mampu bertahan dan berkembang dituntut untuk mampu "berkreasi dan berinovasi sendiri-sendiri” dalam berkompetisi di dunia pendidikan Indonesia secara internal maupun eksternal. Setiap PesantrenMu dituntut untuk melakukan ijtihad dan jihad dalam hal penentuan dan penyelenggaraan sistem pendidikannya sesuai dengan situasi dan kebutuhan daerahnya masing-masing.

Berdasarkan hasil musyawarah forum komunikasi pondok pesantren Muhammadiyah se-Indonesia, biasa disebut dengan istilah Ittihad al-Ma`ahid alMuhammadiyah (ITMAM), tahun 2015 di Sukoharjo, misalnya, dinyatakan bahwa sistem pengelolaan pesantren Muhammadiyah atau berafiliasi dengan Muhammadiyah sangat beragam dan fleksibel. Di antaranya, terdapat PontrenMu berbasis madrasah, sekolah asrama (boarding school), panti asuhan, ${ }^{4}$ sekolah kejuruan, dan lain-lain. Demikian pula dalam hal pengelolaan dan pertanggungjawaban pendirian dan pengelolaannya. Di antaranya terdapat PontrenMu yang didirikan dan dikelola oleh persyarikatan Muhammadiyah berdasarkan ketentuan yang berlaku secara resmi organisatoris, ada pula yang didirikan dan dikelola oleh tokoh atau ahli waris dari tokoh-tokoh kharismatik Muhammadiyah atau didirikan dan dikelola oleh anggota/simpatisan Muhammadiyah, dan lain-lain.

Lalu, menyadari berbagai persoalan itu, Muktamar Muhammadiyah ke-47 di Makassar, 2015 telah memutuskan pembentukan lembaga khusus untuk "menangani persoalan PontrenMu di seluruh Indonesia. Lembaga itu disebut Lembaga Pengembangan

\footnotetext{
${ }^{3}$ Lembaga Pengembangan Pondok Pesantren Pimpinan Pusat Muhammadiyah, Op.Cit., hlm. 10-11

${ }^{4}$ Pesantren Panti Asuhan Yayasan Muhammadiyah, Desa Ie Dingen Kec.Meukek, Aceh
} 
Al-Muaddib : Jurnal IImu-IImu Sosial \& Keislaman http://jurnal.um-tapsel.ac.id/index.php/al-muaddib/ issn online : 2549-0427 | issn cetak : 2528-2492 Volume 1 Nomor 2 ( Januari-Juni) 2019

Pondok Pesantren Muhammadiyah (LP3M) Pimpinan Pusat Muhammadiyah dan kemudian diubah dengan nomenklatur Lembaga Pengembangan Pesantren Muhammadiyah (LP2M) Pimpinan Pusat Muhammadiyah. Kemudian, sebagai langkah awal pembinaan dan pengembangan, lembaga ini kemudian melakukan Rapat Koordinasi Nasional tentang Kurikulum Pondok Pesantren Muhammadiyah di Makassar, pada 28-30 Oktober 2016. Dewasa ini, lembaga ini berhasil dalam menyusun standar pendidikan pesantren Muhammadiyah secara nasional. ${ }^{5}$

\section{A. Pondok Pesantren sebagai Lembaga Pendidikan Islam}

Pesantren, secara etimologis, berasal dari kata santri (bahasa Hindia), berarti tempat tinggal atau tempat belajar santri ${ }^{6}$ (calon biksu/ pedanda alias ahli tentang kitab suci Hindu) atau berasaldari bahasa Tamil, berarti guru mengaji. ${ }^{7}$

Pesantren disebut juga pondok. Kata pondok berasal dari bahasa Arab "fundüq” yang berderivasi dari bahasa Yunani ”pandokheyan” atau "pandokeyon”, berarti penginapan. Dalam penggunaannya, kata pesantren dan kata pondok lazim digabungkan sehingga melahirkan sebuah istilah "pondok pesantren". Padahal, kedua kata itu artinya relatif sama saja.8

Lalu, secara terminologis, pesantren memiliki sejumlah pengertian, di antaranya:

Menurut Mastuhu, pesantren adalah lembaga pendidikan Islam tradisional yang menekankan pentingnya karakter agama Islam sebagai pedoman hidup seharihari.9

Menurut Imam Zarkasyi, pesantren merupakan lembaga pendidikan Islam dengan sistem asrama atau pondok, di mana kyai sebagai figur sentralnya, mesjid sebagai pusat kegiatan yang menjiwainya, dan pengajaran agama Islam dibawah bimbingan kyai yang diikuti santri sebagai kegiatan utamanya.10

Menurut Rofiq S., pesantren adalah sekolah tradisional Islam berasrama dengan memusatkan pengajaran agama dengan menggunakan metode tradisional, mempunyai tata administrasi dan kurikulum yang khas.11

Pesantren, sebagai lembaga pendidikan, pesantren diadopsi oleh para penyiar Islam (khususnya sejak zaman Wali Songo) dari tradisi pendidikan di zaman kerajaan Hindu di Pulau Jawa. Jika pada zaman kerajaan Hindu pesantren berfungsi sebagai pusat pendidikan para calon biksu/pedanda, maka sejak zaman Wali Songo fungsinya diubah dan dikembangkan sebagai pusat pendidikan Islam guna melahirkan calon-calon ahli agama Islam/da’i, khususnya di Pulau Jawa.

\footnotetext{
${ }^{5}$ Lembaga Pengembangan Pesantren (LP2) Pimpinan Pusat Muhammadiyah, Standar Pendidikan Pesantren Muhammadiyah Tahun 2017, (Jakarta: PP Muhammadiyah, 2017).

${ }^{6}$ Departemen Pendidikan dan Kebudayaan Republik Indonesia, Kamus Besar Bahasa Indonesia, (Jakarta: Balai Pustaka, 2001).

7 Zamahksyari Dhofier, Tradisi Pesantren: Studi terhadap Pandangan Hidup Kyai, (Jakarta: LP3S, 1994), hlm. 18. Martin Van Bruinessen, Pesantren and Kitab Kuning: Maintenance and Continuation of a Tradition of Religious Learning, (Berne: The University of Berne Institute of Etnology, 1994).

${ }^{8}$ Bandingkan, Yasmadi, Modernisasi Pesantren, (Jakarta: Ciputat Press, 2002), hlm. 62

${ }^{9}$ Mastuhu, Dinamika Sistem Pendidikan Pesantren, (Jakarta: INIS, 1994), hlm.6

${ }^{10}$ Dikutip dalam Amir Hamzah Wirosukarto, (dkk.), KH. Imam Zarkasyi dari Gontor Merintis Pesantren Modern, (Ponorogo: Gontor Press, 1996), hlm.5

${ }^{11}$ Rofiq S., Pemberdayaan Pesantren, (Yogyakarta: Pustaka Pesantren, 2005), hlm. 1
} 
Al-Muaddib : Jurnal IImu-IImu Sosial \& Keislaman http://jurnal.um-tapsel.ac.id/index.php/al-muaddib/ issn online : 2549-0427 | issn cetak : 2528-2492 Volume 1 Nomor 2 ( Januari-Juni) 2019

Dewasa ini, pesantren terus tumbuh dan berkembang secara natural dengan jumlah sekitar 21.921 (dua puluh satu ribu sembilan ratus duapuluh satu) dengan jumlah santri/santriah sebanyak 3.227.234 (tiga juta dua ratus dua puluh tujuh ribu dua ratus tiga puluh empat).12 Pesantren-pesantren itu, pada umumnya, berafiliasi kepada sejumlah organisasi keislaman, seperti: Nahdlatul Ulama (NU), Muhammadiyah, dan Wahabi/ Salafi. Di samping itu, tidak sedikit pula pesantren yang didirikan dan dikelola secara perorangan ataupun berbentuk yayasan. Pesantren-pesantren yang berkultur NU, misalnya, di antaranya: Pesantren Sidogiri Pasuruan, Pesantren Langitan, Pesantren Lirboyo Kediri, dan lain-lain, pada umumnya, dimiliki dan dikelola secara perseorangan, kekeluargaan, atau yayasan.

Secara tradisional, sebagai lembaga pendidikan Islam pesantren terdiri dari lima unsur utama, yaitu: kyai, santri, mesjid, kitab-kitab kuning, dan pemondokan.13 Kyai menempati posisi sentral dalam sebuah pesantren. Bahkan, hidup matinya pesantren sangat erat kaitannya dengan sosok kharismatik kyai. Di samping sebagai tokoh dan ahli agama yang gugu ilmunya dan ditiru akhlaknya, khususnya oleh para santrinya, kyai juga biasanya berperan sebagai pimpinan atau bahkan pemilik pesantren itu serta sebagai "penarik gerbong” kultur keagamaan.14 Dampaknya, ketika kharismatik kyai sangat kuat pesantrennya biasanya maju dengan pesat dan sebaliknya ketika kyainya tiada seiring dengan ini pesantrennya pun tidak jarang mengalami kemunduran.

Sementara santri merupakan peserta didik di pesantren, dari kalangan lakilaki maupun perempuan. Mereka pada umumnya berusia remaja. Usia sekolah tingkat menengah pertama dan menengah atas. Namun, pada sejumlah pesantren tertentu, para santrinya juga berasal dari kalangan dewasa atau orang-orang tua.

Para santri diharuskan tinggal menetap atau berada di lingkungan pesantren selama 24 jam di bawah pengawasan dan pembimbingan para pendidik atau para pengasuh (asâtidzah) secara total dalam suasana kekeluargaan dan keakraban, sehingga hubungan persaudaraan di antara sesama mereka sangat kuat dengan disertai jiwa kebersamaan, kemandirian, dan kebebasan secara bertanggung jawab.

Dalam pada itu, pesantren menggunakan masjid sebagai pusat kegiatan pendidikan di samping prasarana ritual keagamaan. Kegiatan pendidikan pesantren sebagian besar menggunakan sistem pembelajaran tradisional. Dalam hal ini, biasanya tidak dikenal istilah kritik atau perdebatan antara santri dengan kyai. Sistem pengajarannya menggunakan metode sorogan, wetonan/bandongan, muhâwarah, dan mudzâkarah. Metode sorongan, berarti metode pembelajaran secara tatap muka antara kyai dan santri yang telah dapat membaca Alqur'an atau kitab-kitab kuning berkategori kitab pengantar. Santri dengan membawa kitab tertentu yang dipelajarinya berdasarkan tingkatnya masing-masing satu per satu menghadap kyai. Dalam hal ini, santri mendatangi kyai yang membacakan beberapa ayat Alqur'an atau kitab-kitab kuning berbahasa Arab lalu menerjemahkannya ke dalam bahasa Jawa. Selanjutnya, setiap santri disuruh untuk mengulangi dan menerjemahkannya kata demi kata persis sebagaimana yang

12 https://pontren.com/2018/11/20/jumlah-pondok-pesantren-di-indonesia

${ }^{13}$ Zamahksyari Dhofier, Op.Cit., hlm. 44

14 Bandingkan, Ahmad Mutohar dan Nurul Anam, Manifesto Modernisasi Pendidikan Islam dan Pesantren, (Yogyakarta: Pustaka Pelajar, 2013), hlm. 210. 
Al-Muaddib : Jurnal IImu-IImu Sosial \& Keislaman http://jurnal.um-tapsel.ac.id/index.php/al-muaddib/ issn online : 2549-0427 | issn cetak : 2528-2492 Volume 1 Nomor 2 ( Januari-Juni) 2019

disampaikan oleh kyai/gurunya. Tujuannya, agar santri dapat menguasai bacaan dan memahami teks dari kitab-kitab yang dikajinya secara kebahasaan dengan baik dan benar. Setelah dinilai dapat memahaminya, barulah santri diperkenankan oleh kyai untuk mempelajari kitab tingkat selanjutnya, dan demikian seterusnya. Jadi, metoda sorogan ini diterapkan bagi santri-santri baru tingkat dasar yang masih memerlukan bimbingan khusus secara individual.

Sedangkan metoda wetonan/bandongan merupakan metode pembelajaran secara melingkar (halaqah), di mana kyai/guru membacakan, menerjemahkan, dan menerangkan ayat-ayat Alqur'an atau kitab-kitab klasik berbahasa Arab (kutub safrâ'), sementara para santri (jumlahnya antara 5-500 orang) duduk secara melingkar mendengarkan dan menelaah buku darasnya masing-masing, membuat catatan-catatan tentang kata-kata atau istilah-istilah yang sukar (mufradât), terjemahan-terjemahan atau tafsiran-tafsiran yang dipandang penting dan sulit. Dalam hal ini, para santri senior (kelas enam/tujuh) biasanya diberi kesempatan untuk mengajar kelas halaqah kecil dan oleh karena itu pula, mereka kemudian diberi gelar kehormatan "ustadz muda”.15

Lalu, metode pembelajaran muhâwarah merupakan pembelajaran melalui latihan berkomunikasi atau berdialog dengan sesama masyarakat pesantren dengan menggunakan bahasa Arab terutama dalam membahas kitab-kitab kuning. Sementara metode mudzâkarah merupakan metode pembelajaran dengan cara diskusi dalam suatu acara "seminar ilmiah". Kegiatan mudzâkarah ini bisa dilaksanakan antara kyai dengan para santri dan antara sesama santri senior atau ustadz-ustadz muda. Di dalamnya dibahas kitab-kitab klasik tertentu (al-kutub almu 'tabarah) dengan menggunakan bahasa Arab di bawah asuhan dan bimbingan kyai atau "guru besar". Para ustadz muda yang dinilai sudah matang dengan pengalaman mengajar kitab-kitab mu tabarah itu kemudian diberi gelar kyai muda. Mereka ini, pada umumnya memiliki prestasi terbaik, dan biasanya mereka memperoleh peluang untuk menjadi kyai atau ustadz defenitif di pesantrennya masing-masing.

Dalam pada itu, pesantren-pesantren tradisional itu biasanya mempertahankan tradisi keulamaan masa lalu secara turun temurun, konon sejak zaman Wali Songo. Dalam hal ini, pesantren-pesantren itu memegang teguh prinsip al-Muhâfazah 'ala al-Qadîm al-Şâlih wa al-Akhdzu bi al-Jadîd al-Aşlah " memelihara sesuatu yang lama yang masih cocok dan mengadopsi hal-hal baru yang lebih cocok lagi”. Di antara kultur keberagamaan yang mereka tradisikan adalah ritual tahlilan (biasanya pada malam Jum`at), shalat Subuh dan paruh kedua sholat Tarawih memakai qunut, mengerjakan shalat Tarawih 20 rak'at, mengkaji kitab-kitab kuning (al-kutub al-shafrâ'), pelaksanaan haul dan manaqib tokohtokoh ulama, acara sholawatan, dan lain-lain sebagaimana yang ditradisikan oleh pesantren-pesantren di lingkungan Nahdhatul Ulama (NU).

Di samping bercorak tradisional, terdapat pula pesantren bercorak salafi. Di antara ciri-cirinya adalah16 materi inti pembelajarannya bersumber dari kitab-kitab Islam klasik, sedangkan pengetahuan umum tidak diajarkan sama sekali. Lalu, berbeda dengan kultur pemahaman dan perilaku keberislaman pesantren tradisional

\footnotetext{
${ }^{15}$ Zamahksyari Dhofier, Op.Cit., hlm. 53-54.

${ }^{16}$ Zamakhsary Dhofier, Ibid., hlm. 41
} 
Al-Muaddib : Jurnal IImu-IImu Sosial \& Keislaman http://jurnal.um-tapsel.ac.id/index.php/al-muaddib/ issn online : 2549-0427 | issn cetak : 2528-2492 Volume 1 Nomor 2 ( Januari-Juni) 2019

yang bercorak moderat-akomodatif, kultur pemahaman dan perilaku keberislaman pesantren salafi cenderung sangat konservatif-fundamentalistik, hitam-putih, dan eksklusif. Bahkan, di antara mereka tidak jarang mengkafirkan atau membid ahkan siapa saja atau hal-hal yang dipandang tidak sesuai dengan pemahaman keislamannya. Dalam hal kultur pelaksanaan ritual peribadatan, misalnya, mereka tidak melaksanakan ritual tahlilan, tidak membaca qunut pada shalat Subuh dan paruh kedua sholat Tarawih, dan mereka mengerjakan shalat Tarawih 11 rak’at. Dalam persoalan-persoalan mua `malat, mereka sering merujuk kepada pandanganpandangan keagamaan para ulama Wahabi. Misalnya, mereka memandang tahlil, ziarah kubur, maulid Nabi, dan lain-lain sebagai perbuatan bid’ah, syirik, dan bahkan kufur. Kultur kepesantrenan model salafi ini, di antaranya, dapat ditemukan di Pesantren Umar ibn Khattab di Nusa Tenggara Barat.

Dari aspek sistem pembelajaran, antara pesantren bercorak tradisional dan pesantren bercorak salafi sesungguhnya tidak ada perbedaan yang prinsipal dan menonjol. Kemampuan seorang santri tidak diukur dari tingkat kelasnya, akan tetapi atas dasar kemampuannya dalam membaca, mempelajari, dan memahami sejumlah kitab serta menjelaskannya. Selain itu, penanaman akhlak yang baik terhadap sesama teman, kepada masyarakat dan lingkungan sekitar, terlebih-lebih kepada kyai sangat diutamakan. Bahkan, hubungan batin antara santri dengan kyai, khususnya, tidak hanya berlaku selama proses belajar di pondok pesantren, akan tetapi terus berlangsung hingga santri telah menyelesaikan pendidikannya. Boleh jadi, seorang santri misalnya, pindah ke pesantren lain atau mendirikan pesantren baru, namun silaturrahimnya dengan kyainya tetap terjaga.17

Berkaitan dengan paparan ringkas di atas, muncul pertanyaan bagaimana pula sistem pendidikan PontrenMu. apakah mengacu pada sistem pendidikan kombinasi antara sistem pendidikan tradisional dan sistem pendidikan salafi atau bahkan menggunakan sistem pendidikan alternatif-progressif.

\section{B. PontrenMu sebagai Lembaga Pendidikan Islam Modernis di Indonesia}

PontrenMu secara resmi telah muncul sejak awal 1960-an, khususnya setelah Muktamar Muhammadiyah memutuskan pentingnya Pendidikan Calon Ulama oleh karena kelangkaan ulama kala itu, khususnya di kalangan Muhammadiyah. Selanjutnya, berdasarkan hasil Muktamar ke-39 tahun 1974 di Padang dan diteruskan pada Sidang Tanwir di Yogyakarta, Muhammadiyah melalui Majelis PPK menawarkan pula konsep Pesantren Luhur.18 Keputusan itu kemudian diikuti dengan pendirian sejumlah PontrenMu di Indonesia yang pada masa-masa awal berjumlah tujuh pesantren (pelopor), yaitu:

1. Madrasah Muallimin, Yogyakarta (1918/1932)

2. Madrasah Muallimat, Yogyakarta (1918/1932)

3. Pesantren Muhammadiyah Karang Asem Lamongan, Jawa Timur (1948)

4. Pesantren Muhammadiyah KH Ahmad Dahlan, Sipirok Sumatera Utara (1962)

5. Pendidikan Ulama Tarjih Muhammadiyah (PUTM), Yogyakarta (1968)

6. Pesantren Muhammadiyah Gombara, Sulawesi Selatan (1971)

7. Pesantren Muhammadiyah Darul Arqam, Garut, Jawa Barat (1976)

17 Haidar Putra Daulay, Sejarah Pertumbuhan dan Pembaruan Pendidikan Islam di Indonesia, (Jakarta: Kencana, 2009), hlm. 57

${ }_{18}$ Yusuf Abdullah Puar, Perjuangan dan Pengabdian Muhammadiyah, (Jakarta: Pustaka Antara, 1989), hlm. 225 
Al-Muaddib : Jurnal IImu-IImu Sosial \& Keislaman http://jurnal.um-tapsel.ac.id/index.php/al-muaddib/ issn online : 2549-0427 | issn cetak : 2528-2492 Volume 1 Nomor 2 ( Januari-Juni) 2019

Lalu, dalam perkembangannya, dewasa ini Muhammadiyah memiliki setidaknya 180 pesantren dengan berbagai ragam corak sistem pendidikannya sebagaimana tersebar di hampir seluruh provinsi di Indonesia. Pesatnya pertumbuhan dan perkembangan PontrenMU yang berlangsung sekitar 1968 hingga 1990 itu disertai dengan berbagai corak sistem pendidikan yang diusungnya. Di antaranya, berbasis sistem madrasah, sistem pesantren modern dan kaderisasi, sistem boarding school, sistem pendidikan pesantren tinggi (ma`had âly), dan sistem pesantren sains (trendsains). Namun, secara umum, PontrenMu mengenal dua jenis pesantren, yaitu: Pondok Pesantren Integral dan Pondok Pesantren Takhassus. Pondok Pesantren Integral merupakan pesantren yang berbasis madrasah/sekolah atau madrasah/sekolah yang berbasis pesantren. Sedangkan Pondok Pesantren Takhassus merupakan pesantren yang hanya menyelenggarakan pendidikan keagamaan tertentu guna menghasilkan ulama bidang tertentu. 19

Berbagai PontrenMu itu tersebar di hampir seluruh wilayah Indonesia. Di Sumatera, terdapat sejumlah PontrenMu, yaitu: Pondok Pesantren Muhammadiyah Baitul Arqam Aceh Besar Pondok Pesantren Modern Muhammadiyah Kwala Madu Langkat-Binjai di Sumatera Utara; Pondok Pesantren Muhammadiyah Tanjung Harapan, Kota Solok; Pondok Pesantren Al Kautsar Muhammadiyah, Kabupaten Lima Puluh Kota; Pondok Pesantren Tahfidzul Qur'an Mu’allimin Pakan Sinayan, Kabupaten Agam, Pondok Pesantren Maalip Muhammadiyah, Talamau Pasaman Barat, Pondok Pesantren Moderen Muhammadiyah, Lembah Melintang Pasaman Barat di Sumatera Barat; Pondok Pesantren Modern Muhammadiyah, Duri; Ponpes Modern Darul 'Ulum Kampar Timur, Kab. Kampar, Riau; Pondok Pesantren KH. Ahmad Dahlan Teluk Kuantan, Teluk Kuantan, Kabupaten Kuantan Singingi; Pondok Pesantren Muhammadiyah, Kec.Mandau, Bengkalis di Riau; Pondok Pesantren Islamic Centre Muhamadiyah, Lubuk Linggau Selatan Kota Lubuk Linggau di Sumatera Selatan. Pondok Pesantren Muhammadiyah Curup, Rejang Lebong, Pondok Pesantren Modern Muhammadiyah al-Mubarak, di Bengkulu. Pesantren Budi Mulya Muhammadiyah, Kota Bandar Lampung; Ponpes Muhammadiyah Sabilil Muttaqien Gisting, Kabupaten Tanggamus; Pondok Pesantren Muhammadiyah AtTanwir, Kota Metro, Lampung; Pondok Pesantren Ma'had 'Aly Tarbiyatul Muballighin wa Tahfidzaul Qur'an Muhammadiyah, Kota Metro, Lampung; Ponpes Darul Arqom Muhammadiyah, Metro Pusat, Metro, Lampung; Pondok Muhammadiyah Darul Hikmah, Lampung Timur, Lampung; Pondok Pesantren KH. A. Dahlan, Lampung Utara, Lampung; Ponpes Darul Arqom Kalirejo, Lampung Tengah, Lampung.

Di Jawa, terdapat Pondok Pesantren Al-Furqon Muhammadiyah Boarding School (MBS), Cibiuk, Kabupaten Garut; Pondok Pesantren Amanah Muhammadiyah, Tasikmalaya; Pondok Pesantren Muhammadiyah Darul Arqam, Depok; Pondok Pesantren Muhammadiyah Boarding School, Kota Bekasi di Jawa

${ }^{19}$ PP Muhammadiyah, Ketentuan Majelis Pendidikan Dasar dan Menengah Pimpinan Pusat Muhammadiyah tentang Penyelenggaraan Pesantren, (Jakarta: Majelis Dikdasmen PP Muhammadiyah, 2013), hlm. 76. Lazuardi, Sistem dan Orientasi Pendidikan Pesantren Muhammadiyah di Sumatera Utara (Disertasi), (Medan: Pascasarjana UIN Sumatera Utara, 2018), hlm. 77-83. 
Al-Muaddib : Jurnal IImu-IImu Sosial \& Keislaman http://jurnal.um-tapsel.ac.id/index.php/al-muaddib/ issn online : 2549-0427 | issn cetak : 2528-2492 Volume 1 Nomor 2 ( Januari-Juni) 2019

Barat. Pesantren Mahasiswa KH. Sahlan Rosyidi Unimus Semarang; Pesantren Darul Falah Lasem Rembang; Pesantren Modern MBS Purworejo; Pesantren/Ma`had Stikes Aisyiyah Surakarta; Pesantren Internasional Mas Mansyur UM; Pesantren Hajjah Nuriyah Shabran Surakarta; Pesantren Muhammadiyah Abu Bakar Muntilan Magelang; Pesantren Nurul Quran Bandongan Magelang; Pesantren Tanwirul Fikri Surakarta; Pesantren Nurul Imam Magelang; Pesantren Hj Nasiah Maemanah Muhammadiyah Plompang Sirampog Brebes; Pesantren Muhammadiyah Tempuran Magelang; Pesantren Nurul Huda Sampang; Pesantren Darussalam Demak; Pesantren Modern Darul Arqom Kendal; Pesantren Darul Ihsan Muhammadiyah Sragen; Pesantren Mamba`ul Ulum Boyolali; Pesantren Muhammadiyah Manafiul Ulum Boyolali; Pesantren Muhammadiyah Dukun Magelang; Pesantren Muhammadiyah Sangkal Putung Klaten; Pesantren Imam Syuhodo, Sukoharjo; Pesantren Darul Arqom Ringinarum, Kendal; Pesantren Muhammadiyah Tarbiyatul Mukmin, Magelang; Pesantren Islam Modern Terpadu Muhammadiyah Al-Ma`un, Karanganyar; Pesantren Modern Al Amin Palur, Sukoharjo; Pesantren Modern Darul Ulum Majenang, Cilacap; Darul Arqom Muhammadiyah, Karanganyar; Pondok Pesantren Modern Al-Manaar Muhammadiyah, Pemalang. Pesantren Muhammadiyah Boarding School (MBS) di Prambanan, Sleman, Pesantren Sains (Trensains) Darul Ihsan Muhammadiyah, Sragen, Jawa Tengah. Pondok Pesantren Muhammadiyah Ahmad Dahlan Kabupaten Tegal; Pesantren Muhammadiyah Kudus; Pesantren Miftakhul Ulum Muhammadiyah Pekalongan; Pesantren Al Mu`min Muhammadiyah Temanggung; Pesantren Darul Falaah Mertoyudan Magelang; Pesantren Darul Arqom Tieng Patean Wonosobo; Ponpes Modern Asy-Syifa` Muhammadiyah Blimbingrejo Jepara; PPMTQ Darussalam Muhammadiyah Slinga-Purbalingga; Pesantren Muhammadiyah “Al Furqon“ Cilacap; Pondok Pesantren KH. Mas Mansur Muhammadiyah Wanasari Brebes; Darul Arqom Caruban Ringinarum Kendal; Ali bin Abu Tholib Muhammadiyah Muntilan; Pondok Pesantren Muhammadiyah Tahfidzul Qur`an (PPMTQ) Al Ijtihad Sirau; At Thohiriyah, di Jawa Tengah. Pondok Modern Muhammadiyah Paciran, Lamongan; Pondok Pesantren Karangasem Muhammadiyah Paciran, Lamongan; Pondok Pesantren Al Mizan Muhammadiyah, Banjarmendalan, Lamongan; Pondok Pesantren AlMuttaqin SMK Muhammadiyah Tikung, Lamongan; Pondok Pesantren At-Taqwa Muhammadiyah, Lamongan; Ponpes Muhammadiyah Ulul Azmi Ngimbang, Lamongan; Pondok Pesantren Muhammadiyah Madinatul Ilmi, Gresik; Ponpes AlHikmah Muhammadiyah, Gresik; Pondok Modern Muhammadiyah Pakusari, Jember; Pondok Pesantren Modern Muhammadiyah Boarding School, Trenggalek; Ponpes Insat Muhammadiyah Banyuwangi; Pondok Pesantren Muhammadiyah, Tuban; Pondok Pesantren Muhammadiyah, Pacitan; Pondok Pesantren Muhammadiyah Al-Munawwaroh, Malang; Ponpes Modern Muhammadiyah Salimul Ummah, Magetan; Pondok Pesantren Muhammadiyah, Mayangan, Probolinggo; Pondok Pesantren (PP) Muhammadiyah, Bojonegoro; Pondok Pesantren Al-Ihsan Muhammadiyah, Ngawi Jawa Timur.

Di Sulawesi terdapat Pondok Pesantren Putra Muhammadiyah, Kota Palu, Sulawesi Tengah. Pondok Pesantren Muhammadiyah, Bombana, Sulawesi Tenggara. Pondok Pesantren Darul Arqam Muhammadiyah Balebo, Luwu Utara; Pondok Pesantren Pembangunan Muhammadiyah (Muhammadiyah Islamic 
Al-Muaddib : Jurnal IImu-IImu Sosial \& Keislaman http://jurnal.um-tapsel.ac.id/index.php/al-muaddib/ issn online : 2549-0427 | issn cetak : 2528-2492 Volume 1 Nomor 2 ( Januari-Juni) 2019

Boarding School), Tana Toraja; Pondok Pesantren Darul Arqam Punnia, Pinrang di Sulawesi Selatan.

Lalu, di pulau Kalimantan dan Bali, masing-masing terdapat Pondok Pesantren Nurul Amin Muhammadiyah Alabio, Hulu Sungai Utara, Kalimantan Selatan dan Di pulau Bali terdapat Pondok Pesantren Muhammadiyah Denpasar, Bali dan Pondok Pesantren At-Tanwir Muhammadiyah, Denpasar Utara, Bali.

\section{Sistem Pendidikan PontrenMu}

PontrenMu dapat diklasifikasikan, secara umum, berdasarkan dua aspek utama, yaitu: tingkatan pendidikan dan sistem pendidikan. Berdasarkan aspek tingkat pendidikan, PontrenMu memiliki dua tingkatan, yaitu: PontrenMu Tingkat Menengah dan PontrenMu Tingkat Luhur. Namun, pada umumnya, PontrenMu berkiprah dalam tingkatan pendidikan menengah, yaitu: menengah pertama (tsanawiyah) dan menengah atas (aliyah). Hanya beberapa dari PontrenMu bertipe tingkat pendidikan tinggi (ma`had âly), seperti: Pondok Pesantren Ma'had 'Aly Tarbiyatul Muballighin wa Tahfidzaul Qur'an Muhammadiyah, Kota Metro, Lampung; Pondok Pesantren Luhur Hj. Nuriyah Shabran (1982) Universitas Muhammadiyah Surakarta, Pendidikan Ulama Tarjih Muhammadiyah (PUTM/1968), Yogyakarta, Pesantren Mahasiswa KH. Sahlan Rosyidi Unimus Semarang.

Sementara dari aspek sistem pendidikan, PontrenMu menggunakan tiga sistem, yaitu: sistem pendidikan madrasah, sistem pendidikan Islamic Boarding School, dan sistem pendidikan takhassus. Ketiga sistem pendidikan PontrenMu tersebut digunakan sesuai dengan jenjang pendidikan dan kemampuan serta kapasitasnya masing-masing.

1. PontrenMu Bersistem Madrasah

Pesantren Muhammadiyah (PontrenMU) merupakan salah lembaga pendidikan di lingkungan Muhammadiyah yang memiliki kriteria dan tujuan khusus serta diprogramkan secara formal sebagai tempat penyemaian kader ulama dan calon da i Muhammadiyah, khususnya, yang menguasai ilmu yang bersumber dari ayât qauliyah dan ayât kauniyah. ${ }^{20}$ Dalam konteks PontrenMu bersistem madrasah, biasanya nomenklatur lembaganya disebut Pondok Pesantren Modern Muhammadiyah atau Pesantren Muhammadiyah. Penggunaan istilah "pesantren modern" bertujuan untuk menegaskan identitasnya berbeda dengan pesantren-pesantren tradisional yang lebih sering menggunakan istilah pondok atau mondok. Artinya, sistem pendidikan Islam di PontrenMu bersistem madrasah dikelola dengan menggunakan sistem manajemen pendidikan Islam modern. Sistem pendidikannya mengacu pada sistem pendidikan Islam model Kementerian Agama dan Kementerian Pendidikan \& Kebudayaan Republik Indonesia sesuai dengan UU No. 4/1950 tentang modernisasi pendidikan Islam, UU No.12 Tahun 1954 tentang Pendidikan Agama, dan Keputusan Bersama Tiga Menteri, yaitu: Menteri Agama, Menteri Dalam Negeri, dan Menteri Pendidikan \& Kebudayaan (biasa dikenal dengan istilah SKB Tiga Menteri) tahun $1975 .{ }^{21}$

${ }^{20}$ Lazuardi, Op.Cit., hlm. 23

${ }^{21}$ Laporan Kementerian Agama tahun 1954 dan tahun 1979-1980 sebagaimana dikutip dalam Abdul Munir Mulkhan, Teologi Kiri Landasan Gerakan Membela Kaum Mustad afin, (Yogyakarta: Kreasi Wacana, 2002), hlm. 200 
Dari aspek kyai. Di PontrenMu berbasis madrasah relatif tidak dikenal istilah kyai yang berasosiasi dengan sosok seorang ahli/tokoh agama kharismatik berdasarkan simbol-simbol tradisi keulamaan tertentu, seperti: berlatar belakang pendidikan agama (dari dalam negeri atau negara-negara Timur Tengah), memiliki darah biru keturunan ulama (manâqib), memiliki keramat/kesaktian mitis, menggunakan fashion tertentu dalam hal berpakaian atau memakai aksesoris tertentu (sorban, jubah, kain sarung, syal, peci putih, janggut, dan lain-lain. "Kyai” di PontrenMuh adalah setiap orang yang memiliki kapasitas dan kemampuan di bidang Ilmu-Ilmu Keislaman (ayat qauliyah), Ilmu-Ilmu Kealaman (ayat kauniyah), taat beribadah, berakhlak yang mulia dan bersedia mengemban tanggung jawabnya sebagai ustadz di pesantren. Jadi, fungsi dan tanggung jawab “kekyiaian” terletak pada pundak setiap ustadz/ustadzah (sebuatan bagi guru yang mengajar di pesantren Muhammadiyah termasuk di dalamnya guru Ilmu-Ilmu Agama dan Ilmu-Ilmu non-Agama). Artinya, kekharismatikan sosok kyai di lingkungan PontrenMu menjadi tugas dan tanggung jawab seluruh penyelenggara pendidikan terutama direktur pesantren (mudir) dan guru-guru (asâtidz) yang menetap di lingkungan pesantren. Namun, secara administratif, sistem pengelolaan PontrenMu dipimpin oleh kyiai/ustadz yang menjabat sebagai direktur pesantren (mudir). Dia bertanggung jawab kepada Muhammadiyah c.q. Majelis Pendidikan Dasar dan Menengah (Majlis Dikdasmen) Muhammadiyah setempat atas tugas yang diamanahkan kepadanya selaku mudir pesantren.

Dalam pada itu, aspek kurikulum dan pembelajaran. PontrenMu menggunakan kurikulum madrasah dengan menambahkan pula kurikulum PontrenMu yang berisi materi al-Islam dan Kemuhammadiyahan, bahasa Arab dan bahasa Inggris (Ismubaris), kaderisasi, dan lain-lain. Kurikulum pendidikan itu diajarkan secara bertahap secara semester dan berjenjang sesuai dengan tingkat pendidikan masing-masing, meliputi: tingkat tsanawiyah dan tingkat aliyah. Pendistribusiannya disesuaikan dengan sistem pembagian kelas, yaitu: sejak dari kelas VII hingga kelas IX untuk tingkat tsnawiyah dan sejak dari kelas X hingga kelas XII untuk tingkat aliyah. Di dalam kurikulum itu juga dibubuhkan dan ditetapkan sejumlah kegiatan ekstrakurikuler kepesantrenan dan kemadrasahan. Proses pembelajaran, pembimbingan, dan pengasuhan terhadap para santri-santriah didik tidak mesti dilakukan di ruang kelas, akan tetapi juga di lapangan, mesjid, asrama, dan bahkan alam lingkungan sekitar pesantren. Demikian pula halnya dengan evaluasi hasil pembelajarannya menggunakan sistem evaluasi pendidikan sesuai dengan sejumlah standar pendidikan yang harus diikuti dan dipenuhi sesuai dengan ketentuan yang berlaku secara internal kepesantrenan maupun secara kemadrasahan, dan lain-lain.

Selanjutnya, aspek pengkajian kitab kuning (kutub al-safrâ'). Pengkajian kitab kuning (kutub al-safrâ') relatif jarang dilakukan di PontrenMu bersistem madrasah. Kalupun ada, kegiatan itu biasanya diselenggarakan pada jenjang pendidikan aliyah. Itu pun tergantung pada situasi dan kondisi pesantrennya masing-masing. Artinya, tradisi pengkajian kitab kuning diberikan wewenang sepenuhnya kepada para pengelola pesantren termasuk penentuan kitab-kitab 
Al-Muaddib : Jurnal IImu-IImu Sosial \& Keislaman http://jurnal.um-tapsel.ac.id/index.php/al-muaddib/ issn online : 2549-0427 | issn cetak : 2528-2492 Volume 1 Nomor 2 ( Januari-Juni) 2019

yang dijadikan sebagai kajian. Bagi sebagian PontrenMu bersistem madrasah (terutama pesantren yang sudah maju dan mapan, sebagaimana di beberapa pesantren Muhammadiyah di pulau Jawa,) tradisi pengkajian kitab kuning dilakukan secara kurikuler, terjadwal, dan berkala. Namun, kitab-kitab kuning yang dijadikan sebagai bahan kajian tidak ditentukan secara resmi oleh Muhammadiyah. Di antara kitab-kitab kuning yang biasa dijadikan sebagai bahan bacaan dan kajian adalah kitab-kitab kuning yang berkaitan dengan rujukan dalam pentarjihan di lingkungan Majelis Tarjih Muhammadiyah. Di antaranya, Kitab Tafsir Ibn Katsir, sebagaimana yang dilakukan di Pesantren Muhammadiyah Imam Syuhodo, Sukoharjo, Jawa Tengah,22 Kitâb Tafsîr alManâr, Kitâb Tafsîr al-Marâghî, Kitâb Hadîś Şahîh al-Bukhârî, Kitâb Hadîś Şahîh Muslim, Kitâb Syarh Hadîs al-Bukhârî al-Faţ al-Bârî, Kitâb Syarh Hadîś Muslim, Kitâb Fiqh/Hadîs Al-Muntaqâ karya Ibn Taymiyyah, Kitab Fiqh/Hadis Imam Ahmad ibn Hanbal, Kitab-Kitab Fiqh karya Ibn Qayyim alJauziyyah, Kitab Fiqh Subul al-Salâm, dan lain-lain.

Namun, pada umumnya kajian kitab kuning sangat jarang diselenggarakan secara resmi dan formal di lingkungan PontrenMu berbasis madrasah. Kalaupun terdapat kajian kitab kuning hanya terbatas pada tuntutan diktat atau buku ajar tertentu dan waktu penyelenggaraannya pun sangat terbatas intensitasnya serta terkesan asal jadi alias tidak tersistematisasi secara kurikuler. Dalam pada itu, sangat jarang pula ditemukan PontrenMu yang mengajarkan kitab-kitab induk Tata Bahasa Arab (al-Qawâ`id al-Arabiyyah), di antaranya: Al-Kitâb, Matan Alfiyah, Matan Jurmiyyah, al-Qawâ'id alAsâsiyyah, Al-Kawâkib al-Żurriyyah, Jâmi` al-Durûs al-`Arabiyyah, dan lainlain. Demikian pula halnya terhadap kitab-kitab kuning di bidang kalâm, tasawwuf, târîkh, dan lain-lain.23 Padahal, tidak sedikit lembaga pendidikan kaderisasi ulama itu yang memiliki kitab-kitab kuning yang representatif (mu`tabar).

Agaknya, hal ini tidak terlepas dari "cap pesantren modern” yang melekat pada PontrenMu berbasis madrasah, sehingga meminggirkan tradisi pengkajian kitab-kitab kuning. Boleh jadi pula hal itu disebabkan sistem pendidikan PontrenMu "terjebak" dalam rutinitas sistem pendidikan madrasah model Kementerian Agama Republik Indonesia, di samping sistem rekruitmen calon santri (input) pesantren yang tidak mengkhususkannya meski berasal dari lulusan madrasah, dan lain-lain.

Lalu, aspek masjid. Para santri PontrenMu menjadikan masjid sebagai pusat pelaksanaan ritual ibadah sholat berjamaah lima kali sehari-semalam, kegiatan pengajian Alqur'an, khutbah, dan acara-acara peringatan Hari-Hari Besar Islam (biasanya dalam bentuk ceramah/tabligh), "Hari-Hari Besar Organisasi Muhammadiyah”, dan lain-lain. Masjid juga difungsikan sebagai tempat pelatihan baca Alqur'an, khutbah, imam, penyelenggaraan fardhu kifayah, acara silaturahim, dan lain-lain. Namun, sejumlah kegiatan di mesjidmesjid pesantren Muhammadiyah ditentukan secara otonom dan variatif oleh

22 Hasil wawancara dengan Mudir Pesantren Muhammadiyah Imam Syuhodo, Sukohardjo, Jawa Tengah, Ustadz Yunus, 2017.

${ }^{23}$ http://almuflihun.com/pesantren-muhammadiyah-dan-kitab-kuning-ada-apa/ 16 Januari 2019 
Al-Muaddib : Jurnal IImu-IImu Sosial \& Keislaman http://jurnal.um-tapsel.ac.id/index.php/al-muaddib/ issn online : 2549-0427 | issn cetak : 2528-2492 Volume 1 Nomor 2 ( Januari-Juni) 2019

pembinanya masing-masing dengan memegang teguh prinsip-prinsip pemahaman keislaman Muhammadiyah. Namun, para santri di PontrenMu tidak melaksanakan ritual tahlilan setelah melaksanakan sholat, tidak berqunut pada shalat Subuh dan paruh kedua sholat Tarawih. Mereka mengerjakan shalat Tarawih 11 raka'at, shalat tahajjud (qiyâm al-lail) berjama’ah di mesjid. Lalu, dari aspek pemondokan. PontrenMu menggunakan sistem asrama (pondok) sebagai tempat tinggal para santri secara bersama-sama atau berkelompok-kelompok. Pondok itu disediakan oleh lembaga PontrenMu setempat (biasanya boleh jadi dikelola oleh tingkat pimpinan ranting, cabang, daerah, wilayah, dan pusat). Di lingkungan asrama itu (di lingkungan pesantren Muhammadiyah istilah asrama lebih sering digunakan daripada pondok) para santri/santriah tinggal, hidup dalam kesederhanaan dengan sistem berdikari, dan mereka diatur dengan sistem peraturan tertentu sebagaimana yang ditetapkan oleh pihak pengelola. Sistem asrama sengaja dipilih, di samping oleh karena pertimbangan jauhnya jarak tinggal para santri/santriah dari pesantren sementara mereka membutuhkan waktu belajar (nyantri) dalam waktu yang relatif lama sehingga mengharuskan mereka untuk tinggal di asrama. Sistem asrama juga penting untuk efektivitas dan efisiensi pengorganisasian, pelaksanaan, dan pengawasan terhadap segala kegiatan pendidikan dan pembinaan kepesantrenan termasuk pertimbangan ekonomi dan keamanan.

Penyediaan unit asrama khusus bagi para santri dan para santriah dibuat secara terpisah, namun masih dalam lingkungan pesantren yang sama. Dalam hal ini para santri/santriah harus mengikuti sejumlah persyaratan, ketentuanketentuan, kode etik asrama, dan lain-lain. Sejak dari masalah penentuan ruang kamar, jadwal kegiatan kamar, perlengkapan peralatan tidur, sistem perizinan, sistem pembinaan, dan lain-lain ditentukan secara resmi oleh lembaga pesantren. Biasanya, dalam hal ini pesantren menunjuk petugas khusus untuk "mengurusi masalah asrama secara psikologis, sosial, dan keamanan. Mereka biasa disebut sebagai Bapak/IbuAsrama. Oleh karena itu, sistem tata kelola asrama di PontrenMu, dalam hal ini, menerapkan sistem boarding school daripada sistem pondok sebagaimana yang ditradisikan di pesantren-pesantren tradisional.

Di samping itu, sarana dan prasarana penunjang lainnya, seperti: asrama santri-santriah, lapangan olah raga, bengkel, dapur umum, sarana dan prasaran MCK, kantin, unit kesehatan, koperasi, ruangan kelas, kantor administrasi, dan lain-lain pada umumnya disediakan oleh pendidikan PontrenMu secara swadaya; atau hasil donasi dari para dermawan. Pembangunannya, pada umumnya, berlangsung secara bertahap sesuai dengan kemampuan dan perkembangan pesantrennya masing-masing. Biasanya, PontrenMu didirikan dan dikelola oleh Ranting, Cabang, Daerah, dan bahkan Pimpinan Pusat Muhammadiyah (seperti Muallimin dan Mu`allimat Yogyakarta) atau amal usaha Muhammadiyah (seperti Universitas Muhammadiyah Surakarta mengelola Ma had `Aly Hj. Nuriyyah Shobron). PontrenMu, ada pula yang didirikan oleh perorangan atau tokoh-tokoh kharismatik Muhammadiyah dan sekaligus beliau mengajar di pesantren tersebut. Dalam konteks PontrenMU, 
Al-Muaddib : Jurnal IImu-IImu Sosial \& Keislaman http://jurnal.um-tapsel.ac.id/index.php/al-muaddib/ issn online : 2549-0427 | issn cetak : 2528-2492 Volume 1 Nomor 2 ( Januari-Juni) 2019

kasus seperti ini dapat dilihat dari perjalanan sejarah Pondok Pesantren Karangasem Muhammadiyah Paciran, Lamongan.

Kemudian, dari aspek biaya pendidikan, PontrenMu berbasis madrasah biasanya menerapkan biaya sekolah, biaya asrama, biaya makan, dan biaya perlengkapan sekolah yang relatif terjangkau. Besarannya biasanya ditetapkan berdasarkan hasil musyawarah antara pihak penyelenggara dan orang tua/wali santri-santriah. Atas dasar itu, semua lapisan masyarakat sangat dimungkinkan untuk sanggup membayarnya. Namun, meskipun demikian dalam kenyataannya orang tua/wali santri-santriah tidak jarang banyak juga yang berhutang dan (atau) membayarnya secara bertahap melalui cicilan. Sebab, mereka pada umumnya berasal dari kelas menengah bawah (low middle class). Akibatnya, sejumlah PontrenMu berbasis madrasah tidak jarang mengalami dan menanggung beban ekonomi dalam melangsungkan penyelenggaraan kegiatan pendidikan kepesantrenan berbasis madrasah. Akibatnya, pada umumnya, penyediaan sarana/ prasarana pesantren sering menjadi tersendat-sendat dan kualitasnya juga kurang memenuhi standar dan kurang memadai.

2. PontrenMu Bersistem Islamic Boarding School (MBS)

PontrenMu bersistem Islamic Boarding School merupakan sekolahsekolah Muhammadiyah tingkat menengah pertama dan menengah atas (bahkan ada sejak tingkat Sekolah Dasar) yang mengharuskan sebagian besar atau seluruh peserta didiknya bermukim di asrama sekolah dalam jangka waktu tertentu. Meskipun demikian, dalam hal ini, pihak pengelola sekolah dan asrama berkewajiban memberikan izin bagi siswa untuk pulang ke rumah mereka masing-masing setiap minggu atau memberikan izin masuk setiap hari. $^{24}$ Sekolah-sekolah Muhammadiyah model ini biasanya menamakan dirinya Pondok Pesantren Muhammadiyah Boarding School atau biasa disingkat dengan sebutan PPM MBS atau MBS saja. Tujuannya adalah untuk menanamkan dan menerapkan prinsip-prinsip keislaman dan kemuhammadiyahan dalam hidup keseharian siswa, membentuk akhlak/karakter Islami dan sikap militansi siswa, dan mengembangkan potensi siswa berdasarkan minat, bakat, dan kemampuannya masing-masing sesuai dengan ajaran Islam. Ringkasnya, sistem pendidikan dan pengajaran di MBS berupaya untuk mendidik para siswanya mampu di bidang Ilmu-Ilmu Murni, Ilmu-Ilmu Terapan (skill), dan berpegang teguh pada ajaran agama. Pelaksanaan pendidikannya dilakukan dalam tiga aspek pendidikan, yaitu: kognitif, afektif dan psikomotorik. Atas dasar itu, para alumninya diharapkan dapat menjadi manusia yang memiliki kontribusi besar bagi diri dan keluarganya, bangsa dan negara serta bagi kemanusiaan secara universal.

Dari aspek kyai. MBS, seperti halnya PontrenMu bersistem madrasah, tidak menggunakan istilah kyai sebagai tokoh sentral di bidang pengajaran dan pendidikan. MBS menggunakan istilah kepala sekolah atau direktur bagi pemimpin penyelenggaraan kegiatan pendidikan dan pengajaran. Sementara istilah guru/ustadz dipakai untuk para pendidik di MBS. Mereka berfungsi dan bertanggung jawab sebagai pengajar Ilmu-Ilmu Agama dan Ilmu-Ilmu non-

${ }^{24}$ https://en.wikipedia.org/wiki/Boarding_school 
Agama. Artinya, di lingkungan MBS, tugas-tugas dan sejumlah tanggung jawab berkaitan dengan penyelenggaraan pendidikan dan pengajaran terletak pada (terutama) sosok direktur (mudir) dan guru-guru (asâtidz) yang menetap di lingkungan MBS dengan didukung oleh tenaga kependidikan dan fungsionaris lainnya. Direktur atau kepala sekolah, secara struktural, bertanggung jawab sepenuhnya kepada Majelis Pendidikan Dasar dan Menengah (Majlis Dikdasmen) Muhammadiyah setempat atas amanah yang diberikan kepadanya.

Dari aspek pendidikan dan pengajaran. Dewasa ini, terutama di kota-kota besar, pada umumnya, MBS menyelenggarakan sistem pendidikan dan pengajaran secara integral. Artinya, pembelajaran diselenggarakan dengan menggunakan sistem pendidikan dan pengajaran modern ditambah dengan berbagai kegiatan ekstrakurikuler sampai batas waktu tertentu sepanjang hari (full day). Kurikulum yang digunakan mengacu pada integralisasi Kurikulum Nasional Sekolah model Kementerian Pendidikan dan Kebudayaan Republik Indonesia dan dipadukan dengan Kurikulum Pendidikan Agama versi Kementerian Agama Republik Indonesia dan Kurikulum Majelis Pendidikan Dasar dan Menengah Pimpinan Pusat Muhammadiyah. Konsekuensinya, MBS merancang bangun dan menerapkan kurikulum pendidikan secara komprehensif-holistik. Silabusnya memadukan pembelajaran Ilmu-Ilmu Umum dan Ilmu-Ilmu Agama dengan tetap memberikan porsi persentasi dan waktu lebih besar bagi pembelajaran Ilmu-Ilmu Umum, kegiatan-kegiatan ekstrakurikuler bagi pengembangan kemampuan akademik (academic development), pelatihan-pelatihan tentang kecakapan dan keterampilan hidup (life skill), dan wawasan global. Untuk mendukung keperluan ini, mereka juga tidak jarang mengadakan studi banding ke daerah atau negara lain, di samping mengikuti berbagai kegiatan ilmiah, turnamen, dan pertandingan dengan sekolah-sekolah favorit tingkat nasional maupun regional, dan bahkan tingkat internasional.

Kegiatan pendidikan dan pengajaran dilakukan secara aktif dan demokratis dalam semangat kebersamaan. Para peserta didik saling belajar secara bersama-sama di bawah bimbingan dan arahan dari dewan pendidik dan tenaga kependidikan yang profesional dan berkualitas. Mereka memiliki kemampuan akademik, sosial, spiritual, dan paedagogis yang handal dan terampil. Mereka memberikan pelayanan pendidikan dan pembimbingan atau pembinaan mental siwa selama 24 jam, di antaranya berupa penanaman nilainilai kejujuran, toleransi, tanggungjawab, kepatuhan dan kemandirian sehingga kedekatan antara guru dengan siswa selalu terjaga. Mereka, bahkan berupaya untuk melakukan pemantauan terhadap perkembangan kepribadian siswa dan mencarikan solusi terbaik bagi mereka yang membutuhkan, khususnya atas masalah-masalah yang dihadapi oleh para siswa selama pendidikannya di sekolah. Jadi, sebagaimana di pesantren berbasis madrasah, para guru MBS menjadi figur sentral yang menjadi contoh tauladan bagi para siswa dalam hal bersikap, berperilaku, dan berkreasi-inovasi.

Sebaliknya, para siswa relatif dapat mengetahui setiap aktivitas para guru mereksa selama 24 jam. Para siswa MBS itu, pada umumnya adalah siswasiswa berprestasi di sekolahnya masing-masing yang dijaring berdasarkan 
Al-Muaddib : Jurnal IImu-IImu Sosial \& Keislaman http://jurnal.um-tapsel.ac.id/index.php/al-muaddib/ issn online : 2549-0427 | issn cetak : 2528-2492 Volume 1 Nomor 2 ( Januari-Juni) 2019

sistem penerimaan tertentu sesuai dengan sistem dan pola penerimaan siswa yang diterapkan oleh setiap MBS. Boleh jadi pula mereka dipilih berdasarkan hasil pemantauan potensi minat dan bakat yang dimilikinya sebelum mereka memasuki MBS berdasarkan hasil kerja sama antara MBS dengan sekolahsekolah asal mereka yang pada umumnya juga berkategori favorit sebagaimana tersebar di seluruh daerah Indonesia.

Kemudian, dari aspek kehidupan asrama. Kehidupan para siswa MBS dibina dalam pola kehidupan asrama. Kehidupan mereka dikontrol dengan sistem keamanan tertentu secara total guna menjaga dan menjamin keamanan warga asrama. Tata tertib dibuat untuk seluruh warga di asrama maupun di sekolah beserta ketentuan-ketentuan dan sanksi-sanki serta hukuman bagi pelanggarnya. Akibatnya, lingkungan MBS menjadi kondusif dan terkontrol sehingga dapat memberikan jaminan kualitas ketertiban, keamanan, dan kenyamanan yang lebih terukur jika dibandingkan dengan situasi dan kondisi PontrenMu bersistem madrasah atau sekolah Muhammadiyah bersistem konvensional.

Konsekuensinya, segala aktivitas pendidikan dan pengajaran, pembimbingan dan pembinaan mental dan perilaku keagamaan para siswa dapat berjalan dan terkontrol sebagaimana mestinya secara efektif dan efisien. Tradisi interaktif-positif antara para guru dan kalangan siswa terjalin dengan aktif melalui aktivitas rutin yang telah dijadwalkan. Masalah-masalah para siswa dapat diketahui dengan cepat dan dicarikan solusinya secara tepat. Strategi dan teknik pengajaran ekstrakurikuler MBS dapat terbangun dan dikembangkan secara kreatif-inovatif melalui kegiatan-kegiatan rutin dan terjadwal secara baik. ${ }^{25}$

Selanjutnya, dari aspek sarana dan prasarana. MBS pada umumnya dibangun dengan modal yang cukup besar dan terencana dengan matang oleh Muhammadiyah atau Aisyiah secara swadaya. Biasanya sarana dan prasarana pendidikan dan pengajaran di MBS itu dibangun secara sekaligus dan memiliki kompleks secara integratif. MBS rata-rata memiliki gedung yang relatif mewah dan memiliki berbagai fasilitas yang lengkap, representatif, dan berkualitas. Dalam hal ini, MBS menyediakan berbagai fasilitas terbaik termasuk ruang kriyanya, seperti: masjid, perkantoran sekolah, perpustakaan, laboratorium, ruangan kelas, aula, kantin, lapangan olah raga: tenis, basket, futsal, kolam renang, dan lain-lain. Fasilitas kelas belajar, misalnya, dilengkapi AC, smart board, proyektor, in focus, dan lain-lain. Sementara asrama memiliki fasilitas kamar dengan dilengkapi oleh telepon, TV, AC, lemari es, area pribadi, alat pendeteksi kebakaran, dan lain-lain. Berbagai fasilitas itu digunakan sebagai tempat untuk menyalurkan dan mengeksplorasi kemampuan siswa di berbagai bidang secara kognitif, afektif, dan psikomotorik.

Kemudian, ditinjau dari biaya pendidikan, MBS biasanya menerapkan biaya masuk, uang sekolah, asrama, makan, biaya pembangunan, perlengkapan sekolah, biaya kegiatan ektrakurikuler, dan lain-lain yang relatif mahal di atas rata-rata biaya kebutuhan sekolah di tempat lain. Oleh karena

\begin{tabular}{l}
\hline 25 "Sistem Pendidikan Muhammadiyah Boarding School”, dalam \\
https://www.mbsmuhiba.com
\end{tabular}


Al-Muaddib : Jurnal IImu-IImu Sosial \& Keislaman http://jurnal.um-tapsel.ac.id/index.php/al-muaddib/ issn online : 2549-0427 | issn cetak : 2528-2492 Volume 1 Nomor 2 ( Januari-Juni) 2019

itu, pada umumnya para siswa MBS berasal dari kalangan ekonomi menengah-atas (middle-low high class). Biaya pendidikan itu, biasanya dibayarkan melalui sistem pembayaran on-line atau pembayaran via perbankan. Bahkan, pembayarannya di awal terkadang juga disertai dengan biaya jaminan. Biaya yang relatif mahal tersebut berbanding lurus dengan kualitas pelayanan dan persediaan sarana dan prasarana sekolah yang disediakan oleh pengelola MBS.

Realitas dan fenomena MBS dapat ditemukan di sejumlah sekolah tingkat menengah (SMP/SMA/SMK) Muhammadiyah yang pada umumnya sudah mapan/maju, ${ }^{26}$ sebagaimana tersebar di sejumlah kota di Indonesia (pada umumnya di kota-kota besar Pulau Jawa), seperti: Jakarta, Bogor, Tangerang, Bekasi, Yogyakarta, Sleman, Semarang, Solo, Kalten, Pleret, Bumi Ayu, Malang, Magelang, Bojonegoro, Trenggalek, Tarakan, dan lainlain. Di Yogyakarta, tersebut MBS Yogyakarta yang membina pendidikan sejak tingkat SD, SMP, dan SMA. Di Bojonegoro, terdapat Pondok Pesantren Aisyiah Islamic Boarding School (AIBS), Jawa Timur. Di Malang, terdapat Pondok Pesantren Aisyiah Islamic Boarding School (AIBS), Jawa Timur. ${ }^{27}$

Berbagai MBS itu memiliki kegiatan unggulan dan menonjolkan keunikannya masing-masing. MBS Sleman, Yogyakarta misalnya, mengedepankan program kepesantrenan yang diprogramkan secara harian, mingguan, bulanan, dan tahunan. Program mingguan, misalnya, berupa Muhadharah Sughra, yaitu kegiatan pidato per kelas yang diadakan setiap hari Rabu yang diikuti oleh seluruh siswa/santri maupun santriah dan dipandu oleh para siswa/santri atau santriah senior selaku ketua dan penanggung jawab kelompok. Tempat pelaksanaannya berada di lingkungan pesantren sesuai dengan kesepakatan kelompok. Lalu, penugasan sebagai khatib Juma`at dan guru TPA/TPQ di sekitar pesantren. Program penugasan sebagai khotib Jum'at hanya dikhususkan untuk siswa/santri kelas XII. Sementara penugasan sebagai pengajar TPA/TPQ untuk siswi/santriah di masjid-masjid sekitar MBS. Selain sebagai latihan berdakwah, penugasan ini juga sebagai syarat kelulusan para siswa. Atas dasar itu, setiap siswa harus memenuhi kuota penugasan ini sebagaimana yang ditentukan oleh pihak pengelola pendidikan MBS.

Selanjutnya, MBS Bekasi, mengedepankan empat bidang kegiatan utama kepesantrenan. Pertama, pembinaan akhlak karimah, meliputi: sholat berjamaah, pendidikan al-Islam dan Kemuhammadiyahan, puasa Senin dan Kamis, pembimbingan kelompok (setiap 12 orang santri), dan kegiatan Tapak Suci. Kedua, pembimbingan jiwa keulamaan, meliputi: kultum, muhadharah, mufradat ba`d isya`, Bahasa Arab dan Inggris, educational trip, life skill.

${ }^{26}$ Bandingkan Karel A. Steenbrink, Pesantren Madrasah Sekolah, Pendidikan Islam Dalam Kurun Modern, (Jakarta : LP3ES, 1994).

${ }^{27}$ Di Provinsi Jawa Tengah, misalnya, terdapat MBS Klaten; Pesantren SMP SMA Darul Islam Muhammadiyah Sragen; MBS Zam-Zam Boarding School Cilongok; MBS KH Ahmad Dahlan Ungaran Semarang; MBS SMP Muhammadiyah PK Pracimantoro Wonogiri; MBS Roudhotun Nasyi in (Tahfidz) Jatinom Klaten; MBS Kebumen; IMBS Miftakhul Ulum Pekalongan; dan MBS Wonopringgo, Pekalongan. https://mbs.sch.id/. Keterangan lebih lanjut, lihat "Beberapa Profil Pesantren Muhammadiyah", dalam Warta Ma'had Muhammadiyyah, (Yogyakarta: Toto Adversiting, 1436H), hlm. 3 
Al-Muaddib : Jurnal IImu-IImu Sosial \& Keislaman http://jurnal.um-tapsel.ac.id/index.php/al-muaddib/ issn online : 2549-0427 | issn cetak : 2528-2492 Volume 1 Nomor 2 ( Januari-Juni) 2019

Ketiga, tahfidz Alqur'an, meliputi: muraja `ah ba`d maktubah, tahsin metode ummi, halaqah ba`d subh wa isya', tasmi` kenaikan juz, klub tahfidz, dan klinik Alqur’an. Keempat, kepemimpinan (leadership), dan lain-lain.

3. PontrenMu Bersistem Pendidikan Takhassus

Sistem pendidikan takhassus adalah sistem pendidikan tertentu yang diselenggarakan oleh lembaga pendidikan pesantren tertentu pula. Kurikulumnya khusus, disusun berdasarkan disiplin ilmu tertentu sesuai dengan kebutuhan dan karakteristik PontrenMu, sistem pembelajarannya khusus, dan tujuannya tertentu pula alias pendidikan pesantren spesial. Pondok pesantren takhassus demikian sering disebut, hanya menyelenggarakan pendidikan tertentu di bidang keagamaan guna menghasilkan ulama di bidang itu melalui kolaborasi antara sistem pembelajaran perguruan tinggi dan pendidikan pesantren tradisional. ${ }^{28}$

Tampaknya, Perguruan Ulama Tarjih Muhammadiyah (PUTM), Yogyakarta, misalnya, menggunakan sistem pendidikan takhassus guna mencetak calon-calon ulama di bidang tarjih khususnya di lingkungan Muhammadiyah. Hanya saja dalam hal ini, PUTM yang pendiriannya disponsori oleh Universitas Muhammadiyah Yogyakarta (UMY) dan Universitas Ahmad Dahlan (UAD) Yogyakarta itu, sistem pendidikannya berlevel dan bersistem pendidikan tinggi sebagaimana juga halnya Pondok Pesantren Hj. Nuriyah Shobron, di Universitas Muhammadiyah Surakarta, Solo. Oleh karena itu, ketiga model "pesantren tingkat pendidikan tinggi” itu sehingga disebut juga sebagai Pesantren Budi Luhur. Sementara, di tingkat pendidikan menengah sistem pendidikan takhassus ini diterapkan oleh Pesantren (Muhammadiyah) Al-Manar, Kulon Progo Yogyakarta. ${ }^{29}$

Pada mulanya, sistem pendidikan pesantren takhassus menggunakan metode pembelajaran klasik/tradisional. Metode pembelajarannya menggunakan metode wetonan dengan mengedepankan bahan-bahan ajar dari kitab-kitab kuning di bidang Ilmu-Ilmu Keislaman klasik (al-'ulûm aldîniyyah), seperti: Ilmu Tafsir, Ilmu Hadis, Ilmu Fiqh, Ilmu Tarikh, Ilmu Bahasa dan Sastra Arab, Khitabah, Mantiq, dan lain-lain.

Namun, dalam konteks Pesantren Budi Luhur atau Pesantren Tinggi (Ma`had 'Âly), penggunaan pola pembelajaran klasik diintegralisasikan dengan pola perkuliahan di perguruan tinggi. Artinya, pada level atau semester tertentu, mereka diberi peluang untuk memasuki Fakultas Agama Islam (FAI) di universitas-universitas Muhammadiyah di sekitar tempat pesantren mereka berada. Di FAI itu mereka dapat memilih salah satu jurusan dari berbagai jurusan (meliputi: Jurusan Pendidikan Agama Islam, Jurusan Syariah, Jurusan Dakwah, Jurusan Ekonomi Islam, dan lain-lain) yang diminatinya. Bahkan, tidak jarang asrama pesantren tinggi itu pun juga "berada" di lingkungan kampus tersebut sebagaimana Pondok Pesantren Hj. Nuriyah Shobron yang bertempat di Universitas Muhammadiyah, Surakarta, Solo. Pesantren tingkat tinggi ini, khusus memfokuskan kegiatannya pada upaya membina kaderisasi kepemimpinan di lingkungan Muhammadiyah. Para santri pesantren takhassus ini (mereka berasal dari seluruh penjuru Indonesia dan mereka nyantri

${ }^{28}$ PP Muhammadiyah, Ketentuan Majlis, Loc.Cit.

${ }^{29}$ Lazuardi, Op.Cit., hlm. 80-81 
Al-Muaddib : Jurnal IImu-IImu Sosial \& Keislaman http://jurnal.um-tapsel.ac.id/index.php/al-muaddib/ issn online : 2549-0427 | issn cetak : 2528-2492 Volume 1 Nomor 2 ( Januari-Juni) 2019

dibiayai oleh Muhammadiyah alias beasiswa dari Pimpinan Pusat Muhammadiyah) pada gilirannya dapat memperoleh dua gelar/ijazah (double degrees). Ijazah pertama berasal dari pesantren level tinggi itu, PUTM misalnya, dan ijazah kedua berasal dari fakultas tempat mereka kuliah. Setelah itu mereka bersedia untuk mengabdi di berbagai Amal Usaha Muhammadiyah dan siap untuk ditempatkan di mana saja di seluruh wilayah Indonesia untuk jangka waktu tertentu.

\section{PENUTUP}

Sistem pendidikan PontrenMu bercorak trilogi pendidikan Islam, yaitu: sistem madrasah, sistem Islamic boarding school, dan sistem takhassus. PontrenMU bersistem madrasah merupakan wujud dari modernisasi pesantren bersistem pendidikan klasik/t radisional. Sementara, PontrenMu bersistem Islamic Boarding School dapat dipandang sebagai rekonstruksi sistem sekolah Muhammadiyah konvensional alias wujud “postmodernisasi sekolah-sekolah Muhammadiyah". Sementara PontrenMu bersistem takhassus (Ma`had Âly), dalam tataran tertentu, merupakan wujud neo-postmodernisme PontrenMu bersistem Islamic Boarding School sebagai hasil dari upaya elaborasi secara integral sistem pendidikan pesantren klasik/tradisional dengan sistem pendidikan perguruan tinggi. Ketiga sistem pendidikan PontrenMu itu merupakan suatu terobosan bagi pengembangan sistem pendidikan Muhammadiyah dalam menghadapi dan menjawab tantangan di bidang pendidikan sesuai dengan jenjangnya masing-masing di zaman kekinian yang sangat kompetitif, di samping untuk memenuhi tuntutan perubahan sosial masyarakat sesuai dengan situasi dan kondisi sosial-ekonominya masing-masing.

\section{DAFTAR PUSTAKA}

Bruinessen, Martin Van. Pesantren and Kitab Kuning: Maintenance and Continuation of a Tradition of Religious Learning. Berne: The University of Berne Institute of Etnology, 1994

Daulay, Haidar Putra. Sejarah Pertumbuhan dan Pembaruan Pendidikan Islam di Indonesia. Jakarta: Kencana, 2009

Dhofier, Zamahksyari. Tradisi Pesantren, Studi Pandangan Hidup Kyai dan Visinya Mengenai Masa Depan Indonesia. Jakarta: LP3ES, 2011.

Lazuardi, Sistem dan Orientasi Pendidikan Pesantren Muhammadiyah di Sumatera Utara (Disertasi). Medan: Pascasarjana UIN Sumatera Utara, 2018

Lembaga Pengembangan Pondok Pesantren Pimpinan Pusat Muhammadiyah, Draft Kurikulum Pondok Pesantren Muhammadiyah Tahun 2016. Jakarta: PP Muhammadiyah, 2016

Lembaga Pengembangan Pesantren (LP2) Pimpinan Pusat Muhammadiyah, Standar Pendidikan Pesantren Muhammadiyah Tahun 2017. Jakarta: PP Muhammadiyah, 2017

Mastuhu. Dinamika Sistem Pendidikan Pesantren. Jakarta: INIS, 1994

Mulkhan, Abdul Munir. Teologi Kiri Landasan Gerakan Membela Kaum Mustad afin. Yogyakarta: Kreasi Wacana, 2002 
Al-Muaddib : Jurnal IImu-IImu Sosial \& Keislaman http://jurnal.um-tapsel.ac.id/index.php/al-muaddib/ issn online : 2549-0427 | issn cetak : 2528-2492 Volume 1 Nomor 2 (Januari-Juni) 2019

Mutohar, Ahmad dan Anam, Nurul. Manifesto Modernisasi Pendidikan Islam dan Pesantren. Yogyakarta: Pustaka Pelajar, 2013.

Pimpinan Pusat Muhammadiyah, Laporan Pimpinan Pusat Muhammadiyah Periode 2010-2015. Jakarta: PP Muhammadiyah, 2015.

---------Ketentuan Majelis Pendidikan Dasar dan Menengah Pimpinan Pusat Muhammadiyah tentang Penyelenggaraan Pesantren. Jakarta: Majelis Dikdasmen PP Muhammadiyah, 2013.

Puar, Yusuf Abdullah. Perjuangan dan Pengabdian Muhammadiyah. Jakarta: Pustaka Antara, 1989

Steenbrink, Karel A. Pesantren Madrasah Sekolah, Pendidikan Islam Dalam Kurun Modern. Jakarta : LP3ES, 1994.

Warta Ma `had Muhammadiyyah. Yogyakarta: Toto Adversiting, $1436 \mathrm{H}$

Wirosukarto, Amir Hamzah (dkk.), KH. Imam Zarkasyi dari Gontor Merintis Pesantren Modern. Ponorogo: Gontor Press, 1996.

Yasmadi, Modernisasi Pesantren. Jakarta: Ciputat Press, 2002.

http://almuflihun.com/pesantren-muhammadiyah-dan-kitab-kuning /16Januari 2019 https://en.wikipedia.org/wiki/Boarding_school https://mbs.sch.id/ https://pontren.com/2018/11/20/jumlah-pondok-pesantren-di-indonesia https://www.mbsmuhiba.com 